Japan. J. Breeding Vol. 20, No. 6 : 344 350 (1970)

\title{
DIFFERENCES IN LEAF PHOTOSYNTHESIS AND LEAF TRANSPIRATION RATES AMONG SIX COMMERCIAL WHEAT VARIETIES OF WEST PAKISTAN*
}

\author{
Muhammed Amin KHAN** and Shigesaburo TsunODA \\ Laboratory of Plant Breeding, Faculty of Agriculture, \\ Tohoku University, Sendai 980
}

\begin{abstract}
Synopsis. Mexi-Pak, a modern high yielding semi-dwarf whert variety with high response to fertilization showed higher photosynthetic rate and higher transpiration rate per unit leaf area as compared with old Pakistani varieties. High photosynthetic rate was associated with high transpiration rate, high specific leaf weight and high nitrogen content per leaf area. Percentage of leaf nitrogen content to leaf dry matter was also high in Mexi-Pak.
\end{abstract}

\section{Introduction}

Differences in photosynthesis of single attached leaves in intense light and $300 \mathrm{ppm}$ $\mathrm{CO}_{2}$ have been observed among cultivated wheats and its wild relatives including diploid, tetraploid and hexaploid species having spring and winter habits of growth (KHAN and TsuNODA, 1970ac). It was reported that the wild species in general and wild diploid species in particular, having "thick" and small leaves, showed higher photosynthetic rates per unit leaf area as well as higher nitrogen content in comparison to "thin" and large leaves of cultivated tetraploid and hexaploid species which showed a lower nitrogen content and lower photosynthetic rate per leaf area. However, this low nitrogen content per leaf area was associated with the enlargement of leaf area which may bring about an increased utilization of solar radiation under a properly balanced water supply.

This investigation was initiated in order to find out if differences could be detected between different varieties regarding their photosynthetic activity and other leaf characters with some old and modern commercially cultivated wheats of West Pakistan. In the case of a modern wheat cultivar which shall

\footnotetext{
Received October 7, 1970.

* This work has been supported by a scholarship from the Ministry of Education, Japan, which is gratefully acknowledged.

** Graduate student from West Pakistan Agricultural University, Lyall Pur. (West Pakistan).
}

be dealt with in this paper, the change from "thin, large" leaves towards "thick, small" leaves seems to be going on under abundant supply of nitrogen and properly balanced water supply resulting in an increased utilization of solar radiation, as in the case of modern rice varieties which has already been stated (Tsunoda, 1959).

\section{Materials and Methods}

The seeds of six commercially cultivated wheat varieties of West Pakistan shown in Table 1 and Fig. 1 were germinated in petridishes in incubator at about $20-25^{\circ} \mathrm{C}$ and after germination they were planted in plastic pots $(9 \mathrm{~cm}$ diameter by $20 \mathrm{~cm}$ height) containing river silt in the glass-house in different three experiments on November 18 th, 1967 ; December 1st, 1968 ; and May 7 th, 1969 ; respectively. Two Seedlings were planted in each pot, one plant was left after thinning for the examination. Pots were randomized at planting and repositioned randomly at various times during the course of experiments. The plants were irrigated daily and large plants were watered twice a day if necessary. A nutrition solution (Ammonium sulphate $47 \mathrm{~g}$, Sodium phosphate dibasic $25 \mathrm{~g}$, and Potassium chloride $12 \mathrm{~g}$ in 1 litre of water) was applied at the rate of $10 \mathrm{~m} l$ per pot before planting. and afterwards every 10-15 days interval.

The photosynthesis of full expanded individual leaves attached to the intact plants was observed in a transparent glass chamber under artificial light. The concentration of $\mathrm{CO}_{2}$ in 
Table 1. Characteristics of the West Pakistani Commercial Wheat Varieties

\begin{tabular}{|c|c|c|c|c|}
\hline $\begin{array}{l}\text { S. } \\
\text { No. }\end{array}$ & Variety & $\begin{array}{l}\text { Year of } \\
\text { approval }\end{array}$ & Parentage & General Characters \\
\hline 1. & C 228 & 1941 & $\begin{array}{l}\text { Hard Feder- } \\
\text { ation } \times 9 \mathrm{D}\end{array}$ & $\begin{array}{l}\text { Plants tall, weak stemmed, ears bearded rather lax } \\
\text { and smooth. Grains amber and of good quality. Sus- } \\
\text { ceptible to three rusts. It was recommeneded for late } \\
\text { sowings. }\end{array}$ \\
\hline 2. & C 271 & 1957 & C $230 \times$ IP 165 & $\begin{array}{l}\text { Plants tall somewhat stiff stemmed. Ears beardless, } \\
\text { mid lax, glumes pubescent, grains amber and bold. } \\
\text { Resistant to stripe rust but highly susceptible to leaf } \\
\text { and stem rusts. It was recommended for rich soils. }\end{array}$ \\
\hline 3. & C 273 & 1957 & C $209 \times$ C 591 & $\begin{array}{l}\text { Plants tall, ears bearded, mid dense, glumes white; } \\
\text { grains amber and of good quality. Susceptible to three } \\
\text { rusts, It was recommended for irrigated lands. }\end{array}$ \\
\hline 4. & C 518 & 1933 & Type $9 \times 8 \mathrm{~A}$ & $\begin{array}{l}\text { Ears bearded, densely fitted. Awns greyish black. } \\
\text { Susceptible to three rusts. Stem better than C } 591 \text {. } \\
\text { It was recommended for rich soils. }\end{array}$ \\
\hline 5. & C 591 & 1934 & Type $9 \times 8 \mathrm{~B}$ & $\begin{array}{l}\text { Plants tall, bearded, Susceptible to three rusts, grains } \\
\text { amber and attractive. It was recommended for irri- } \\
\text { gated lands. }\end{array}$ \\
\hline 6. & Mexi-Pak & 1966 & $\begin{array}{c}\text { Penjamo } \times \\
\text { Gabo }\end{array}$ & $\begin{array}{l}\text { Plants semi-dwarf, stiff stemmed and high tillering } \\
\text { and yielding wheat variety. Ears bearded with higher } \\
\text { number of florets. Grains amber and of medium } \\
\text { quality. Resistant to stem and stripe rusts but moder- } \\
\text { ately susceptible to leaf rust. }\end{array}$ \\
\hline
\end{tabular}

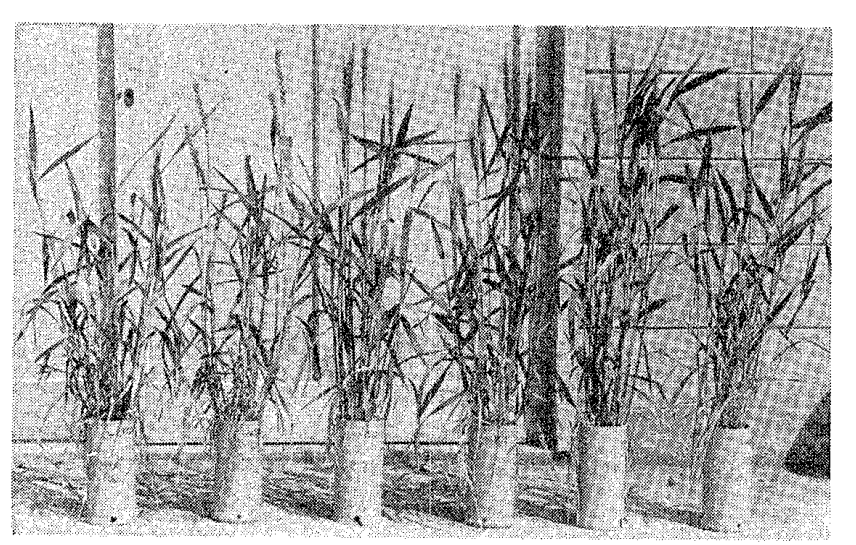

Fig. 1. Appearance of full grown specimens of the six commercial cultivated wheats of West Pakistan, used in all the experiments. The plants shown here have been cultured in glass-house. The varieties are from left: Mexi-Pak, C271, C273, C518, C 591 and C228.

the air entering and leaving the chamber was measured by means of Hitachi-Horiba EIA-1A infrared $\mathrm{CO}_{2}$ gas analyzer in which the air temperature was kept at $20^{\circ} \mathrm{C}$.

In order to study response to air flow rates, the leaves were exposed to $300 \mathrm{ppm} \mathrm{CO}_{2}$ and temperature was maintained within a range of $20-23^{\circ} \mathrm{C}$ while air flow rates passing through the leaf chamber were changed from 0.5 to 2.0 litres per minute.

The methods of measuring and calculating the leaf photosynthetic rate, leaf area, leaf dry weight and leaf nitrogen content were the same as described in a previous paper (Khan and Tsunoda, 1970a).

For evaluating the transpiration rate, the dry-bulb and wet-bulb temperatures of the air entering and leaving the leaf chamber were measured with the aid of Iio MIC-165 high sensitivity thermometer. The moisture content at the entrance and the exit was calculated to evaluate the transpiration rate.

\section{Results and Discussions}

\section{EXPERIMENT 1. Photosynthesis, leaf nitrogen and specific leaf weight and their interrelationships.}

Photosynthetic rate per unit leaf area $\left(P_{A}\right)$ estimated on the basis of 1.0 litre air flow rate and nitrogen content per leaf area are found to be positively correlated with a correlation coefficient value of $\mathrm{r}=+0.574$ being significant at $1 \%$ level (Fig. 2). A further look into Fig. 2 and Table 2 indicated that a modern cultivated highest yielding wheat variety namely Mexi-Pak gave the highest photosynthetic rate per unit leaf area as. well as nitrogen content per leaf area followed by a variety C 228. There existed significant differences between Mexi-Pak and the remaining old varieties with respect to the photosynthetic rate as well as nitrogen content per leaf area. 
Table 2 and Fig. 3 very clearly revealed that variety Mexi-Pak followed by variety C 228 gave the highest specific leaf weight values and there existed significant differences between Mexi-Pak and the remaining four old varieties. Moreover, it is quite obvious from Fig. 3 that there is a strong positive correlation between photosynthetic rate per unit leaf area and specific leaf weight (leaf dry weight per unit leaf area) with a correlation coefficient value of $\mathrm{r}=+0.574$ which is statistically highly significant at $1 \%$ level. A higher $P_{A}$ of variety Mexi-Pak seems to be associated with a higher specific leaf weight and a lower $P_{A}$ of variety C 273 with a lower specific leaf weight. Pearce et al. (1969) showed that there was a strong

Table 2. Means and least significant differences.

\begin{tabular}{|c|c|c|c|c|c|c|c|}
\hline & \multirow[b]{2}{*}{ Varieties } & \multicolumn{4}{|c|}{ Experiment 1 (March, 1968) } & \multicolumn{2}{|c|}{ Experiment 3 (June, 1969) } \\
\hline & & \begin{tabular}{|c|} 
Photosynthetic \\
rate per unit \\
leaf area \\
$\left(\mathrm{mgCO}_{2}\right.$ \\
$\left.\mathrm{dm}^{-2} \mathrm{hr}^{-1}\right)$ \\
\end{tabular} & $\begin{array}{l}\text { Nitrogen } \\
\text { content per } \\
\text { leaf area } \\
\left(\mathrm{mg} / \mathrm{dm}^{2}\right)\end{array}$ & $\begin{array}{c}\text { Specific leaf } \\
\text { weight } \\
\left(\mathrm{mg} / \mathrm{cm}^{2}\right)\end{array}$ & $\begin{array}{l}\text { Nitrogen } \\
\text { percent } \\
\text { content per } \\
\text { leaf dry } \\
\text { weight }\end{array}$ & $\begin{array}{l}\text { Photosynthetic } \\
\text { rate per unit } \\
\text { leaf area } \\
\left(\mathrm{mgCO}_{2}\right. \\
\left.\mathrm{dm}^{-2} \mathrm{hr}^{-1}\right)\end{array}$ & $\begin{array}{l}\text { Transpiration } \\
\text { rate } \\
\left(\mathrm{mg} \mathrm{H}_{2} \mathrm{O}\right. \\
\left.\mathrm{cm}^{-2} \mathrm{hr}^{-1}\right)\end{array}$ \\
\hline 1. & C 228 & 33.8 & 23.3 & 5.52 & 4. 46 & 28.0 & 8.9 \\
\hline 2. & C 271 & 30.5 & 20.5 & 5.19 & 3.65 & 27.1 & 11.5 \\
\hline 3. & C 273 & 28.6 & 21.3 & 5.21 & 4.16 & 24.9 & 8.1 \\
\hline 4. & C 518 & 30.1 & 19.9 & 5.05 & 4.16 & 27.3 & 10.4 \\
\hline 5. & C 591 & 31.5 & 21.0 & 5.03 & 4.62 & 30.1 & 10.8 \\
\hline 6. & Mexi-Pak & 36.0 & 25.3 & 6.16 & 4.97 & 34.0 & 12.6 \\
\hline & LSD at $5 \%$ & 4.3 & 1.6 & 0.74 & 0.54 & 7.9 & 1.9 \\
\hline & $\mathrm{LSD}$ at $1 \%$ & 5.8 & 2.2 & 1.00 & 0.73 & 11.3 & 2.7 \\
\hline
\end{tabular}

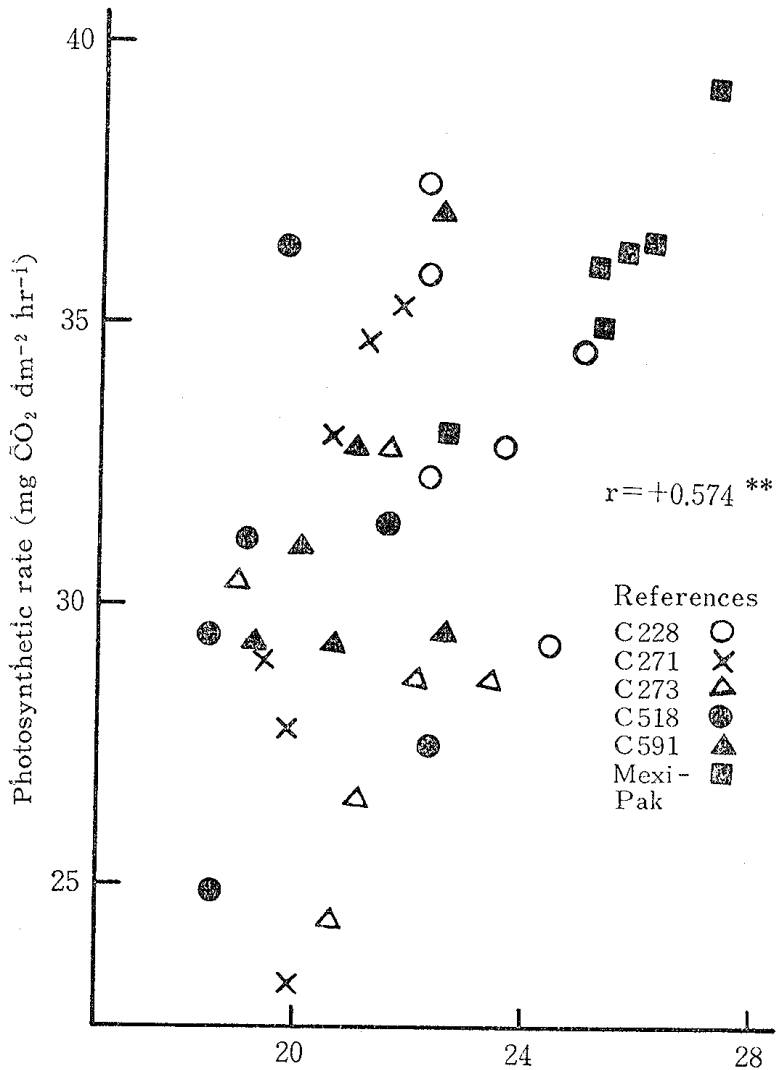

Nitrogen content $\left(\mathrm{mg} / \mathrm{dm}^{2}\right)$

Fig. 2. Relationship between nitrogen content and photosynthetic rate. (March, 1968) ** Significant at $1 \%$ level.

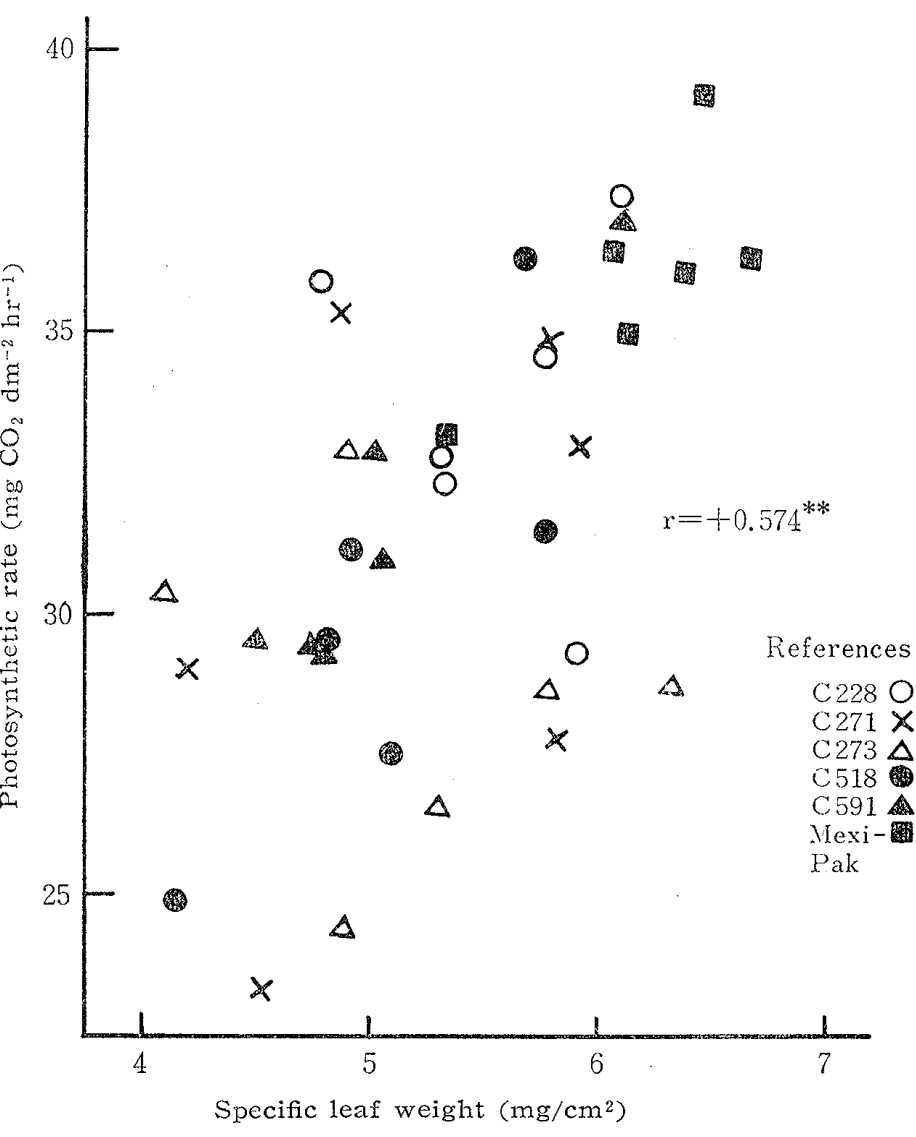

Fig. 3. Relationship between specific leaf we:ght and photosynthetic rate. (March, 1968). 
positive correlation between photosynthetic rate per leaf area and the specific leaf weight among strains of alfalfa. The same correlation was observed by Murata (1961) among rice varieties and by OJIMA and Kawashima (1968) among soybean varieties at least on the leaves of the plants at early stages of growth. Similar type of correlations have been observed on strains of different species of Triticum and Aegilops (Khan and Tsunoda, $1970 \mathrm{bc}$ ). The results from the present studies on West Pakistani wheat varieties lend a strong support to these findings.

The correlations observed between photosynthetic rate per unit leaf area and nitrogen content per leaf area (Fig. 2) almost resembles with that observed between photosynthetic rate per unit leaf area and specific leaf weight (Fig. 3).

Fig. 4 reveals a strong positive correlation between specific leaf weight and leaf areal nitrogen content with a correlation coefficient value of $r=+0.707$ statistically highly significant even at $1 \%$ level. Here again in case of variety Mexi-Pak, with the increase in nitrogen content per leaf area, an increase in the specific leaf weight is seen very clearly. These results coincide with the findings of $K_{\text {HAN }}$ and TSunOda (1970bc).

The contents of Table 2 clearly indicated

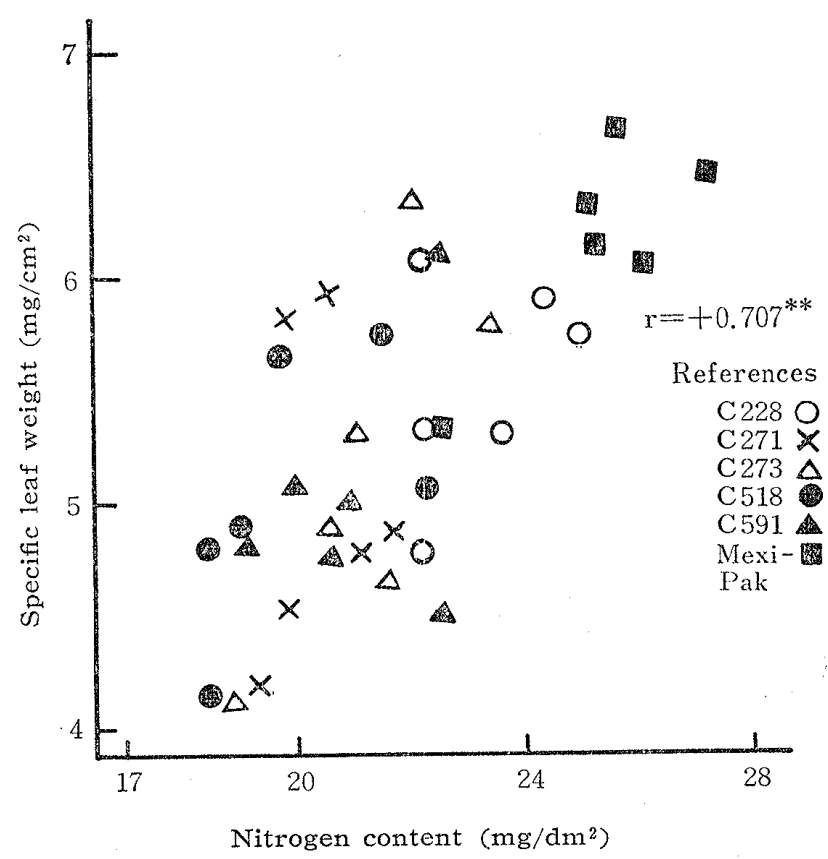

Fig. 4. Relationship between nitrogen content and specific leaf weight. (March, 1968) that variety Mexi-Pak showed also the highest percent of nitrogen content per leaf dry weight followed by variety C 591 and C 228 . It can be further seen that there existed' significant differences between Mexi-Pak and the remaining old wheat varieties at $5 \%$ level of least significant difference. In rice as well as well as in sweet potatoes, varieties adapted to heavy manuring tended to show a high percentage content of nitrogen in the leaf blade, as compared with those adapted to light: manuring (TsuNODA, 1953; 1959; and 1960). BABA (1954) also pointed out that, in rice, that Japanese varieties fitted for heavy manuring showed, in general, a high percentage content of nitrogen as compared with varieties. of indica types fitted for light manuring. The findings of this investigation agree with those of other workers mentioned above. From these results it may be suggested further that the percentage content of nitrogen in the leaf blade is worthy of attention to the varietal responsiblity to fertilization.

K HAN and Tsunoda (1970a) described that wild plants tended to have "thick" small leaves showing high $P_{A}$ values while cultivated wheats with "thin" large leaves showed low $P_{A}$ values. Further, it was considered that this change from "thick" small leaves towards "thin" large leaves may have been proceeded in accordance with improved water supply. However, it should be mentioned that the cultivated types observed in the previous paper were mainly primitive cultivars. In the case of some modern wheat cultivars such as MexiPak, the change of just reverse direction, i.e., from "thin" large leaves towards "thick" small leaves seems to be going on under abundant supply of nitrogen and other nutrients. It is worthy of mention here about the modern cultivated wheat variety of West Pakistan, Mexi-Pak, that it is adapted to heavy manuring and gives per acre yield as high as almost the double under heavy fertilization and properly irrigated conditions as compared with the old commercial wheat varieties of West Pakistan. Besides, when compared the depth of green colour of the leaves, Mexi-Pak variety showed very dark green colour as compared to other varieties which are having: light green colours. It has been reported by 


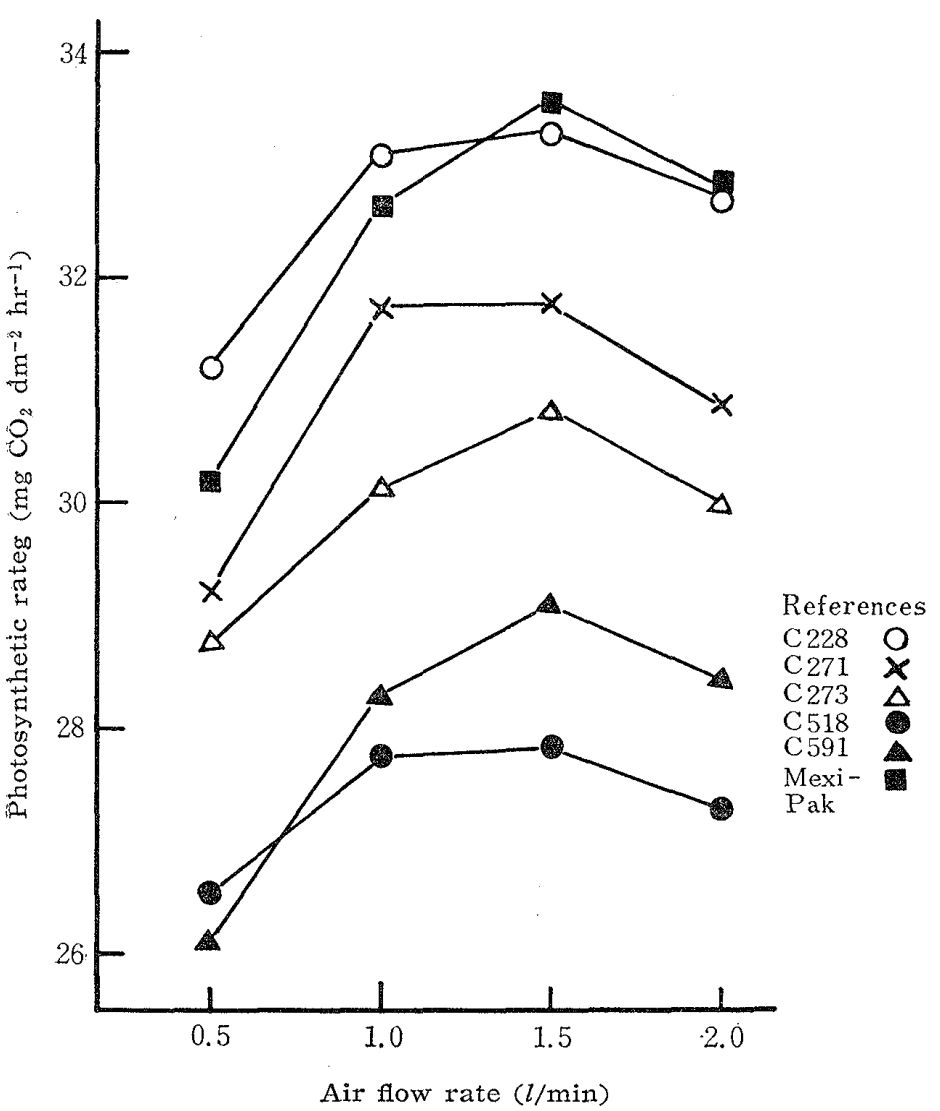

Fig.5. Influence of air flow rate on photosynthetic rate in commercial wheat varieties of West Pakistan. (January, 1969)

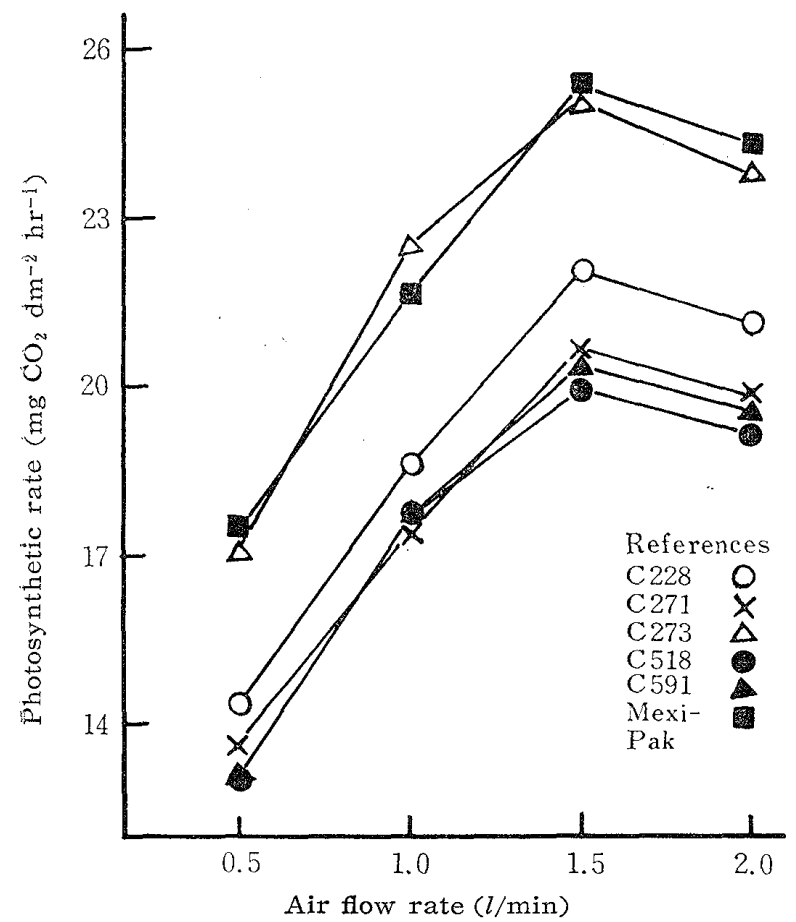

Fig. 6. Influence of air flow rate on photosynthetic rate in commercial wheat varieties of West Pakistan. (March, 1969)
Tsunoda (1959) that the varieties adapted to light manuring tended to have "thin" horizontal and thinly dispersed leaves and it should not or need not be coloured so deep. Whereas, "thick" leaves, vertical leaves and densely gathered leaves, are the characteristics of the varieties adapted to heavy manuring and tend to be deeply coloured to absorb as much light as possible.

EXPERIMENT 2. Influence of different air flow rates on leaf photosynthesis.

The influence of different air flow rates on leaf photosynthesis in diploid, tetraploid and hexaploid species have been reported elsewhere (KHAN and TSUNODA, $1970 \mathrm{c})$. It was pointed out that depending upon the leaf sizes, the highest photosynthesis was obtained at 1.0 litre air flow rate in case of diploid species which have smaller leaves or smaller single leaf area, while 1.5 litre gave the highest photosynthetic rates in case of tetraploids and hexaploid species having larger leaf sizes or larger single leaf area.

In the present investigation, the materials used are all cultivated common bread wheats, cultivars of hexaploid Triticum vulgare Vill. Here again the influence of different air flow rates on attached single leaves was studied in an attempt to know whether intraspecific differences could be detected between these materials. The results are presented in Figs. 5 and 6.

The data regarding the lst observation, i.e., January, 1969 are presented in Fig. 5. It is quite obvious that all the varieties showed lower photosynthetic rates at lower air flow rates, i.e., 0.5 and 1.0 litres, whereas at 1.5 litre, all the varieties showed the highest photosynthetic values and at 2.0 litres it decreased again. At the optimum air flow rate, it is quite clear that variety Mexi-Pak followed by $\mathrm{C} 228$ and $\mathrm{C} 271$ varieties gave the highest photosynthetic rates. Varieties C 591 and C 518, which were released in the 1930's, showed the lowest photosynthetic values.

The data for the 2 nd observation, i.e., 
March, 1969, are presented in Fig. 6. A through look into Fig. 6 indicates that at low air flow rates $P_{A}$ values are low while the maximum $P_{A}$ values are attained at 1.5 litres and again a tendency of decreasing $P_{A}$ is observed here with the increase of air flow rate, i.e., at 2.0 litres. Here again Mexi-Pak variety followed by $\mathrm{C} 273$ and $\mathrm{C} 228$ showed the highest $P_{A}$ values whereas C591 and C 518, very old commercial varieties released in the 1930's gave the lowest $P_{A}$ values.

While comparing the data of January with that of March, it is quite evident that with a few exceptions, almost results are the same in both the cases. However, in January's data, the $P_{A}$ values are higher in general as compared with March observations. The reason may be either temperature or environmental differences or differences in single leaf areas. The second difference is that during March observations, there is a sharp increase in $P_{A}$ values as compared with January's observations.

It coincides with the results already described in the previous paper that 1.5 litre air flow rate is the proper and adequate to get the highest photosynthetic rates in case of hexaploid varieties under our present system of measuring $P_{A}$.

EXPERIMENT 3. Leaf photosynthesis and leaf transpiration and their interrelationships.

The calculations for photosynthetic rates per unit leaf area and transpiration rates in this experiment were made on 1.5 litre air flow rate basing on the results of the preceding experiment that 1.5 litre air flow rate is proper and adequate to get the highest photosynthetic rates in case of hexaploid species. A very strong positive correlation was observed between photosynthetic rate per unit leaf area and transpiration rate (Fig. 7). A correlation coefficient value of $\mathrm{r}=+0.728$ significant at $1 \%$ level was seen. A higher photosynthetic rate seems to be associated with a higher transpiration value and a lower photosynthetic rate with a lower transpiration rate.

Furthermore, it can be pointed out from Table 2 and Fig. 7 that variety Mexi-Pak exhibited highest photosynthetic rates per unit leaf area as well as transpiration rates among the materials under investigation. Variety C 273 gave the lowest photosynthetic rate and

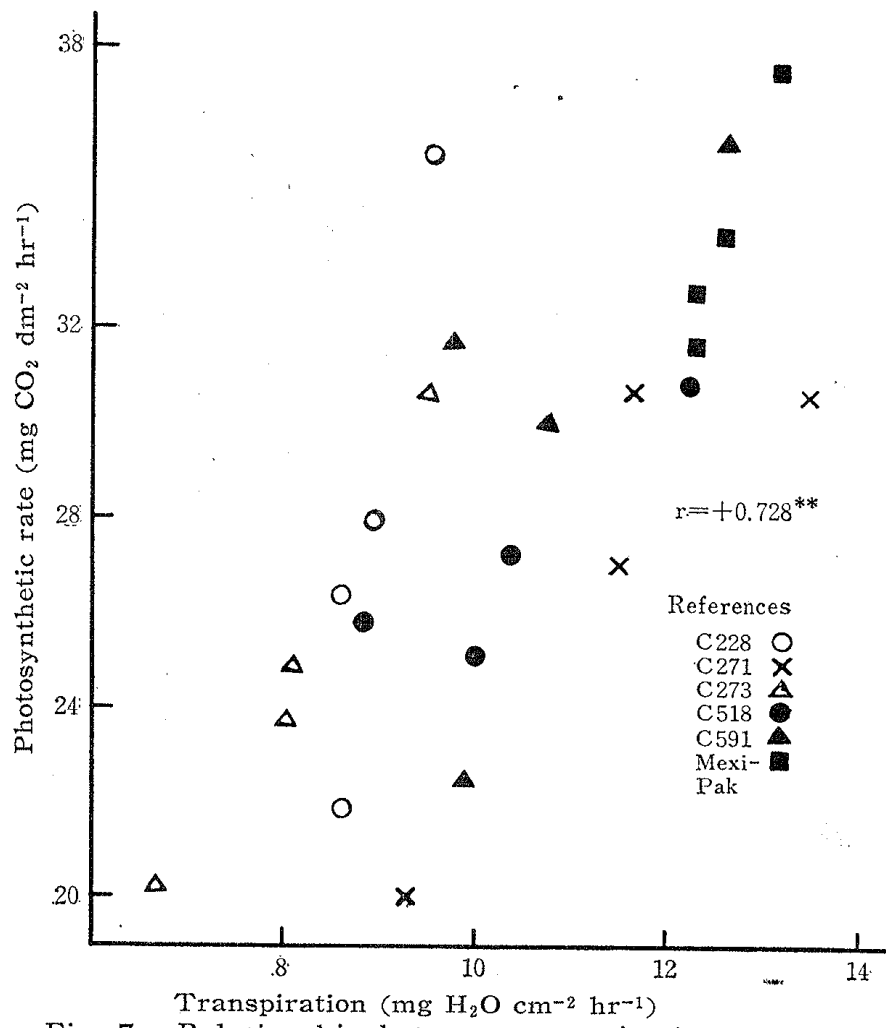

Fig. 7. Relationship between transpiration and photosynthetic rate. (June, 1969)

transpiration values whereas the remaining varieties namely C 591, C 271, C 518 and C 228 gave the intermediate values in this respect. There existed significant differences between variety Mexi-Pak and C 273 for the photosynthetic rate as well as transpiration rate (Table 2). These findings resemble with that of already reported on strains of different species of Triticum and Aegilops (KHAN and Tsunoda, $1970 \mathrm{c}$ ) that photosynthetic rates per unit leaf area and transpiration rates are highly correlated positively.

\section{Summary}

Differences in photosynthetic rate per unit leaf area and transpiration rate of single attached leaves were observed among six commercially cultivated wheat varieties of West Pakistan. Mexi-Pak, a modern semidwarf variety that yields high under heavy fertilized and properly irrigated conditions showed higher photosynthetic rate and higher transpiration rate on leaf area basis than old Pakistani wheat varieties. High photosynthetic rate was associated with high transpiration rate, high specific leaf weight and high nitrogen content per leaf area. Percentange of leaf nitrogen content to leaf dry matter 
was also high in Mexi-Pak as compared with old varieties.

In the previous papers it was pointed out that wild species of Triticum and Aegilops tended to have "thick" small leaves showing higher photosynthetic rates per leaf area while cultivated wheats with "thin" large leaves showed low photosynthetic rates. Further, it was considered that this change from "thick" small leaves towards "thin" large leaves may have been proceeded in accordance with improved water supply. In the case of some modern wheat cultivars such as Mexi-Pak, the change of just reverse direction, i.e., from "thin" large towards "thick" small leaves seems to be going on under abundant fertilizer supply.

The influence of different air flow rates passing through the leaf chamber was studied on the same materials. The results coincided with those reported in the previous paper that 1.5 litre per minute air flow rate is the proper and adequate to get the highest photosynthetic rates in case of hexaploid varieties under our present system of measuring photosynthetic values.

\section{Literature Cited}

BABA, I., 1954. Breeding of rice variety for heavy manuring. Japan. J. Breeding. 4, Separate Vol. $167 \sim 184$.

KHAN, M. A., and S. TSUNODA., 1970a. Evolutionary trends in leaf photosynthesis and related leaf characters among cultivated wheat species and its wild relatives. Japan. J. Breed. 20 : 133 140.
KHAN, M.A., and S. TSUNODA., 1970b. Growth analysis of cultivated wheat species and their wild relatives with special reference to the dry matter distribution among different plant organs and to leaf area expansion. Tohoku. J. Agri. Res. $21: 47$ $\sim 59$.

KHAN, M. A., and S. TSUNODA.. 1970c. Leaf photosynthesis and transpiration under different levels of air flow rate and light intensity in cultivated wheat species and its wild relatives. Japan. J. Breed. $20: 305 \sim 314$.

MURATA, Y., 1961. Studies on the photosynthesis of rice plants and its culture significance. Bull. Natl. Inst. Agr. Sci. (Nishigahara), Ser. D $9: 1$ 170.

OJIMA, M., and R. KAWASHIMA., 1968. Studies on the seed production of soybean. 5. Varietal differences in photosynthetic rate of soybean. Proc. Crop Sci. Soc. Japan. $37: 667 \sim 675$.

Pearce, R. B., Carlson, G. E., Barnes, D. K., Hart, R.H., and C.H.HANSON., 1969. Specific leaf weight and photosynthesis of alfalfa. Crop Sci. $9: 423 \sim$ 426.

TSUNODA, S., 1953. Comparison of the rice varieties suitable for fertile or for hungry land. Proc. Crop Sci. Soc. Japan. $21: 209 \sim 210$.

TSUNODA, S., 1959. A developmental analysis of yielding ability in varieties of field crops. II. The assimilation-system of plants as affected by the form, direction and arrangement of single leaves. Japan. J. Breed. $9: 237 \sim 244$.

TSUNODA, S., 1960. A developmenta1 analysis of yielding ability in varieties of field crops. III. The depth of green colour and the nitrogen content of leaves. Japan. J. Breed. 10: 107 111.

西パキスタン栽培小麦 6 品種の葉光合成, 葉蒸散率の差異

\section{A. KHAN・角田重三郎}

（東北大学農学部）

西パキスタンの栽培小麦 6 品種について着生単葉の単 位葉面積当りの光合成，蒸散率の差異を锥察した。多肥 で適当に灌渐される条件下で高い収量を上げる最新の半 矮性品種，Mexi-Pak が汨来のパキスタン小麦品種に 比べ菜面放たり高い光合成率，高い蒸散率を示した。高 い光合成率惊，高い蒸散率，高、葉面当り乾物量，高い 葉面当り窒素量と相伴なつていた。葉乾物沉対する葉窒 素の含有比も Mexi-Pak の方が古い品種比比べ高か つた。

前報で，小麦属，Aegilops 属の影生種は “厚い”小型 葉を持ち葉面当り光合成率が高く，一方践培小麦は “薄

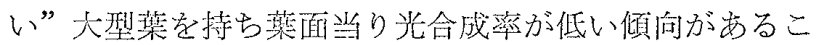
そ, 更に, この “厚い”小型葉から“薄い” 大型葉への 变化は水分供給の改善にとるなつて進行した可能性が亦 ることが指摘された。 Mexi-Pakのような近代的な小韭 栽培品種の場合《は，ちようど逆の“薄い”大型葉から “厚い”小型葉への変化が閵沢な肥料施用の下で進行して いる場合も市るよう火見うけら机る。

同化箱の通気速度の影響を同じ材料沉ついて調查した。 結果は前報と同じく，6 倍性品種の場合には每分 1.5 l の通気速度が現装置に和いて最高光合成率を得るの適 当十分なるのであつた。 